\title{
Caithness revisited: Robertsonian chromosome polymorphism in Caithness house mice
}

\author{
P. N. Scriven* and \\ P. C. Brooker $\dagger$
}

\author{
* S.E. Thames Regional Genetics Centre, \\ Guy's Hospital, Prince Philip Laboratories, \\ Guy's Tower 8th Floor, St Thomas Street, \\ London SE1 9RT, U.K. \\ † Department of Mutagenesis and Cell Biology, \\ Huntingdon Research Centre Ltd., Huntingdon, \\ Cambs., PE18 6ES, U.K.
}

The purpose of this communication is to revise and clarify the position regarding house mouse populations with Robertsonian chromosomes in the northern Scottish county of Caithness.

Several years ago Adolph and Klein (1981) described three Robertsonian translocations in nine mice caught near Castletown in the north of Caithness. All were homozygous for $\mathrm{Rb}(4.10)$ and $\mathrm{Rb}(9.12)$; eight were homozygous for $\mathrm{Rb}(6.13)$, the other was heterozygous for this fusion. Hence, eight of the mice had a diploid chromosome number of $34(2 n=34)$, the other was $2 n=35$. Shortly afterwards Brooker (1982) confirmed this finding and reported also 12 other Robertsonian translocations in 31 Caithness house mice from 18 locations in the county.

In 1985, one of us (PNS) caught and karyotyped ten animals from three locations in Caithness (table 1). Somatic karyotype analyses were made from G-banded metaphse spreads of peripheral blood lymphocytes obtained by orbital sinus puncture and culture (adapted from the methods of Triman, Davisson and Roderick, 1975; and Buckland, Evans and Sumner, 1971). Only four Robertsonian translocations were found, those described by Adolph and Klein (1981), plus Rb(11.14) described in Brooker (1982).

Since no mouse has been found within Caithness with less than 32 chromosomes (indicative of only four cestric fusions), it seemed necessary to re-examine the earlier material. Analysis of photographs and negatives (slides having deteriorated badly) led us to agree that only four Robertsonian translocations seem to be represented in Caithness: Rbs(4.10), (6.13), (9.12) and Rb(11.14) (Fig. 1). Table 1 shows those individuals where the karyotype was determined without equivocation. Although the sample sizes are small (one or two individuals in most cases), each centric fusion has a widespread distribution within Caithness. To date all Caithness house mice are homozygous for $\mathrm{Rb}(9.12)$ and $\mathrm{Rb}(4.10)$ (with one exception in 37 mice karyotyped), but some are segregating for $\mathrm{Rb}(6.13)$ and $\mathrm{Rb}(11.14)$.

To the north, three of the Orkney islands have house mice with centric fusions (Adolph and Klein, 1981; Brooker 1982; Nash, Brooker and Davis, 1983). All mice with Robertsonian chromosomes in this region share $\mathrm{Rb}(9.12)$ suggesting they have a common origin. Excluding $\mathrm{Rb}(6.13)$ (which is also found in the $C D$ race of central Italy; Capanna, Civitelli and Cristaldi, 1977), no Scottish Robertsonian translocations have been reported elsewhere to our knowledge.

In summary, Caithness house mice have four Robertsonian translocations. They are homozygous for $\mathrm{Rb}(9.12)$ and $\mathrm{Rb}(4.10)$, and segregate for $\mathrm{Rb}(6.13)$ and $\mathrm{Rb}(11.14)$. These results do not adversely affect Caithness's relationship with other Robertsonian populations (see Larson, Prager and Wilson, 1984). However, Caithness mice are obviously less curious than previously thought. 


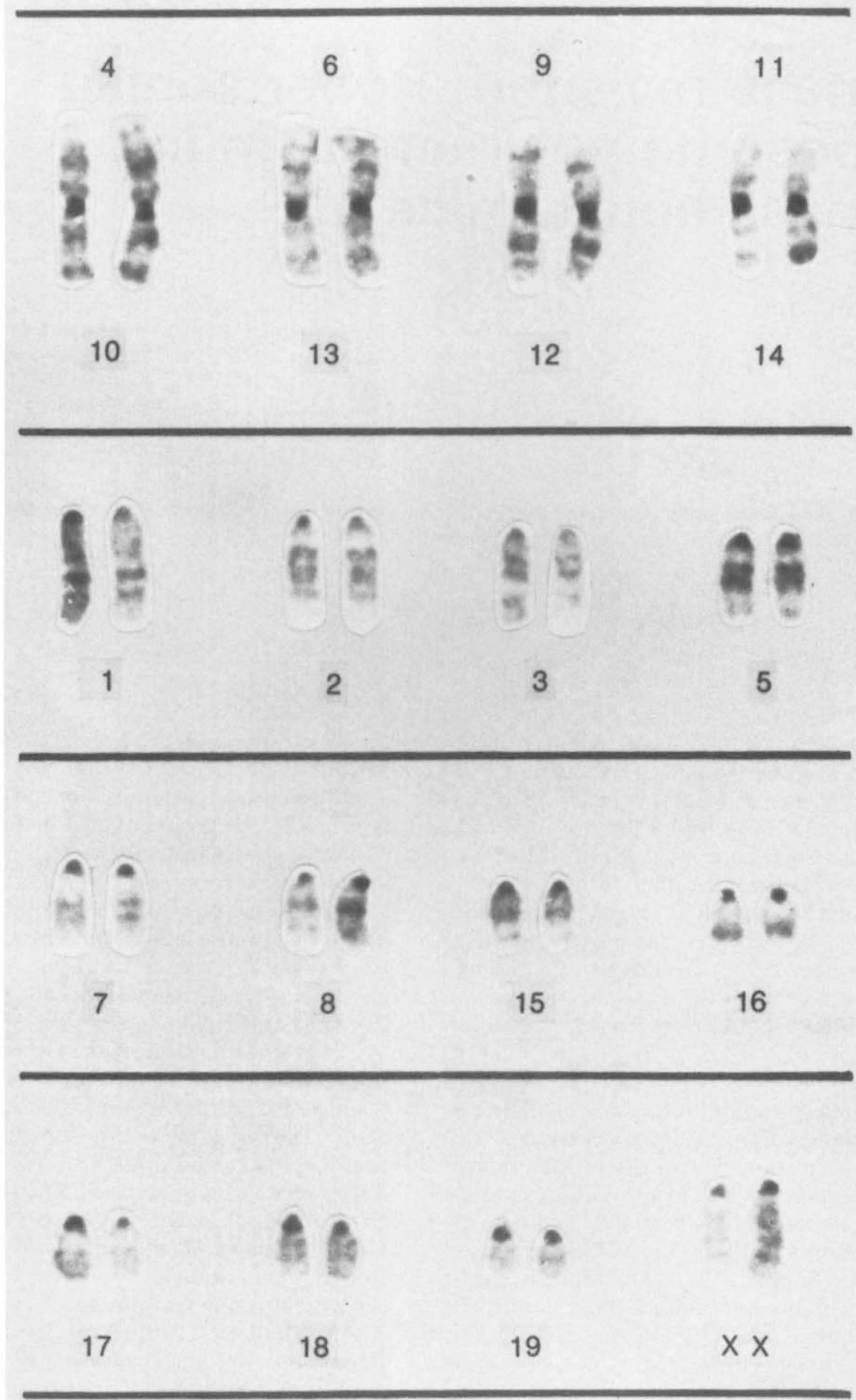

Figure 1 G-banded karyotype of the house mouse caught at location eight, $2 n=32$, N.F. $=40$. 
Table 1 Analysis of house mice caught in Caithness

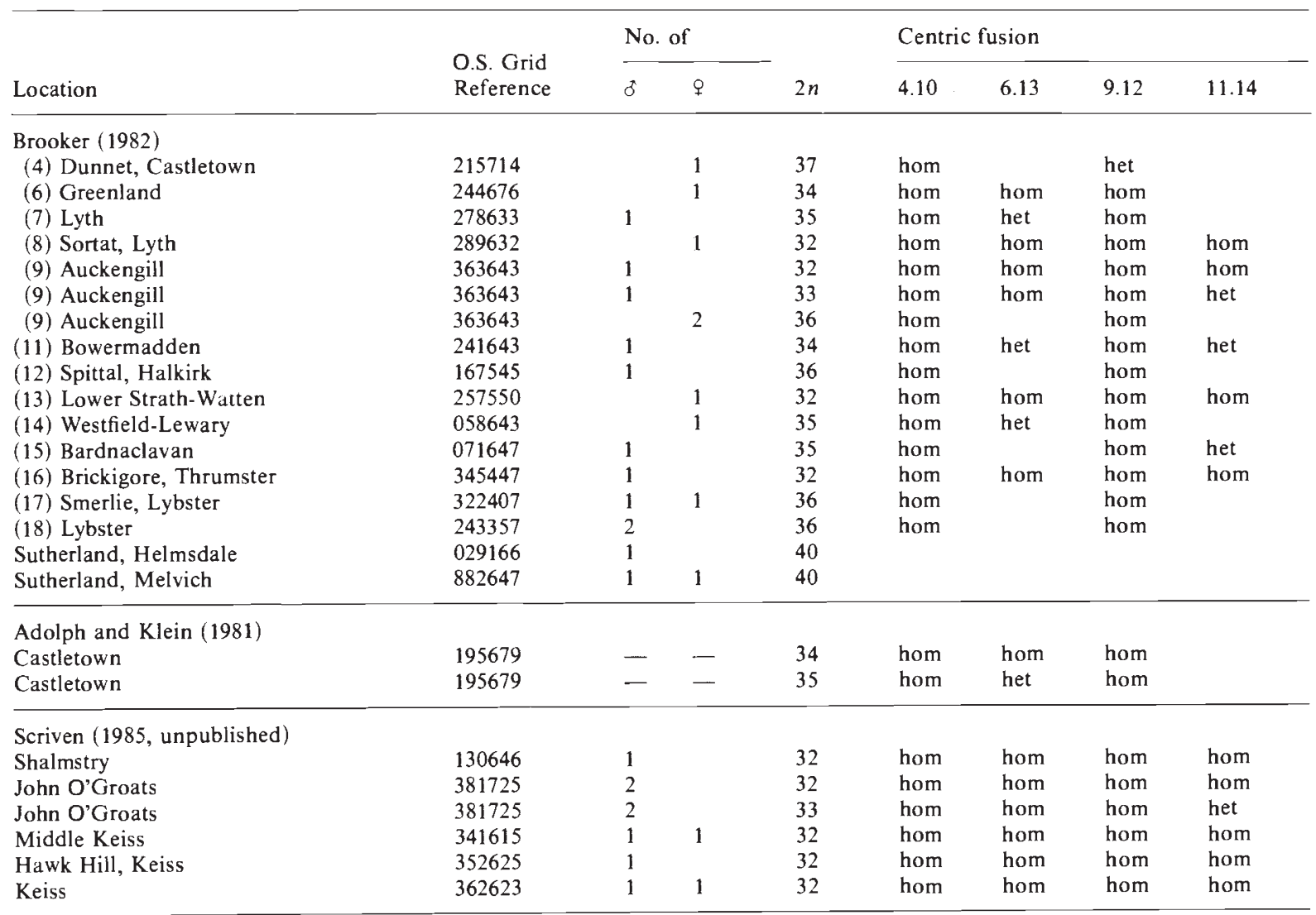

Acknowledgement P.N.S. was supported by a grant from the Natural Environment Research Council.

\section{REFERENCES}

ADOLPH, S. AND KLEIN, J. 1981. Robertsonian variation in Mus musculus from central Europe, Spain and Scotland. J. Hered., 72, 219-221.

BROOKER, P. C. 1982. Robertsonian translocations in Mus musculus from N.E. Scotland and Orkney. Heredity, 48, 305309.

BUCKLAND, R. A., EVANS, H. J., AND SUMNER, A. T. 1971. Identifying house mouse chromosomes with the ASG technique. Exp. Cell Res., 69, 231-236.
CAPANNA, E., CIVITELli, M. V., AND CRISTALDi M. 1977. Chromosomal rearrangement, reproductive isolation and speciation in mammals. The case of Mus musculus. Boll. Zool., 44, 213-246.

LARSON, A., PRAGER, E. M., AND WILSON, A. C. 1984. Chromosomal evolution, speciation and morphological change in vertebrates: the role of social behaviour. Chromosomes Today, 8, 215-228.

NASH, H. R., BROOKER, P. C., AND DAVIS, S. J. M. 1983. The Robertsonian translocation house-mouse populations of north east Scotland: A study of their origin and evolution. Heredity, 50, 303-310.

TRIMAN, K. L., DAVISSON, M. T., AND RODERICK, T. H. 1975. A method for preparing chromosomes from peripheral blood in the mouse. Cytogenet. Cell Genet., 15, 166-176. 